\title{
Assessment and Documentation of Indigenous and Introduced Soil and Water Conservation Practices in Selected Districts of SNNPRS, Ethiopia
}

\author{
Zemede Amado Ephrem Assefa \\ Hawassa Agricultural Research Center, SARI, P. O. Box 06, Ethiopia
}

\begin{abstract}
In Ethiopia, soil erosion is the major problem which caused food security problem among rural households. Soil and water conservation is the only way to protect, control and manage soil erosion caused by water, wind and farming practices. In many parts of Ethiopia particularly southern Region many introduced and indigenous soil and water conservation measures were practiced using different approach. But, different indigenous and introduced SWC practices implemented were not assessed, identified and documented well yet. This study identified different indigenous and introduced SWC practices including their implementing system, function, category, and implementing season of each practice. The cropping system and its function, and the limitations of implementing SWC practices were also assessed. The study was undertaken at Layigna Arisho, M/gortanicho kebeles of Wera Zuria district, Tanakaka Umbullo and Kajima Umbullo of Hawassa Zuria district, Tutitti and worabi kebeles of Yirga Chafe district. The results show that at all study kebele's there was a practice of both indigenous and introduced SWC practices. Indigenous SWC practices are basic for introduced practices. There were different indigenous practices which were practiced at specific district but not at other district.

Keywords: Soil erosion, indigenous soil and water conservation measures, introduced soil and water conservation measures.
\end{abstract}

DOI: $10.7176 / \mathrm{JEES} / 10-1-04$

Publication date: January $31^{\text {st }} 2020$

\section{Introduction}

Recently, the depletion of natural resources is among major problems facing humans throughout the world. The International soil Reference and Information Centre (1995) estimated that nine million hectares of the world lands are tremendously degraded and their original biotic functions are severely degraded. Land degradation, which includes degradation of vegetation cover, soil and nutrient depletion, is a major ecological and economical problem in Ethiopia (Haileslassie etal, 2005). High soil erosion rates as a result of steep slopes, continuous encroachment and cultivation of marginal lands, long history of deforestation, over grazing; negative coping strategies, such as the burning of animal dung, extensive use of charcoal, reduced rotation periods are among the major cause of land degradation (Teklu Erkossa et.al., 2002).

Soil erosion is a global environmental problem causing the loss of fertile top soil and reducing the productive capacity of the land and thereby raises the risk of global food security. It causes the loss of agricultural productivity and a decline of water quality. It is estimated that about 10 million ha of cropland is lost in the world due to soil erosion every year and is often a Common occurrence in the Mediterranean and China. The Soil Conservation Research Project (SCRP) has estimated an annual soil loss of about 1.5 billion tons from the Ethiopian highlands. The Ethiopian highlands have been experiencing declining soil fertility and severe soil erosion due to intensive farming on steep and fragile land (Abegaz, 1995). According to the Ethiopian Highlands Reclamation Study (EHRS, 1984) soil erosion is estimated to cost the country 1.9 billion US\$ between 1985 and 2010. Soil erosion and nutrient depletion presents a threat to food security and sustainability of agricultural production in many developing countries (Betru, 2003). Ethiopia losses around 2 billion tons of fertile soil and subsequently losses $2 \%$ of the annual grain production, which is roughly equivalent to 120, 000 tons of cereal per annum (Mesfin, 2004). According to Mesfin (2004), the annual loss in grain production due to erosion in 2000 was 170,000 tones. This shows the loss of income in terms of lost agricultural production of US \$150 million.

Soil conservation is the only known way to protect the productive land (Panda, 2007). It can be undertaken by using and managing the land based on the capabilities of the land itself involving application of the best management practices leading to profitable crop production without land degradation (Panda, 2007).

In Ethiopia, Soil and water conservation activities were started after the famines of 1973 and 1985 with different program launched by government (GOs and NGOs) from which food-for-work program was implemented for long time (Hoben,1996). Following this program, different physical and biological soil and water conservation measures were implemented by community collective action as well as farmers' personal trial. On the other way, different land enhancing technologies and practices have been introduced by research institutions, extension and other development practitioners in the region (Wagayehu and Lars, 2003).

Indigenous soil and water conservation is the method used by different farmers to facilitate optimum level of 
production from a given area of land while keeping soil loss below a critical value. The soil loss tolerance value is defined as the rate of erosion at which soil fertility can be maintained over at least 25 years (Hurni, 1983). Indigenous soil and water conservation practices have very often been ignored or underestimated by development agents, researchers, soil conservationists and government staff (IFAD, 1992). Although the objectives of knowing indigenous soil and water conservation practices give us an understanding of farmers' way of thinking about the measures (Hudson, 1992). Farmers use a number of indigenous soil and water conservation technologies to prevent the problem of soil erosion. Among these are cut- of -drains, leaving crop residues in the field, distribution of manure, contour farming, fallowing, , planting root crops by preparing bunds, tree planting on slope farm, use of trash lines on contour, row planting, alley cropping, intercropping, strip planting, and plantation of Sisal (Agave sisalana Perrine) and euphorbia (Euphorbia classenii) on the farm etc. According to Genene M. and Abiy G. (2014), most of the farmers in south western Ethiopia practices introduced and indigenous soil and water conservation activities like; contour farming, furrow making, residue leaving, agronomic practices, putting trash lines on contour etc.

Appropriate soil and water conservation technologies are those which offer for a given production situation an optimal solution for using the land for sustainable and productive agricultural purposes. Appropriate technologies are not necessarily "simple" technologies. However, in the context of many developing countries, the appropriate technologies will be ones which are not capital-intensive and which use local resources and the existing labor force in an optimal way.

It should be emphasized that before introducing a new technology it is necessary to check whether local soil and water conservation measures already exist and why and how farmers apply these indigenous technologies. If such technologies exist and continue to be applied by farmers, then, providing they have not been introduced and maintained by legal force and state authority, they can be considered successful and on investigation will be found to provide tangible benefits. Understanding the reasons why farmers use such technologies, i.e. the production and conservation benefits they get from them, is the key to the successful introduction of any "new" technology, which must at least match and preferably improve on the benefits to be obtained from the existing ones (CARDI, 2010).

The effect of soil and water conservation measure in reducing soil loss generally varies with soil type, land use, land cover, topography, climate and intensity of the measures. Among the factor major contribution for reducing erosion is from farming system in general and land use land cover specifically. In this regard the major factors are related to every day activity of land owner/farmers/. Therefore, they protect their soil indigenously for their crop productivity. Different authors assessed many indigenous soil and water conservation ( ISWC) practices that can reduce soil loss however it was not organized as a form of integrating its historical analysis, source, and property, technical social, economical and cultural aspects. So, this project was identified and investigated different Indigenous and introduced that could add value on reducing soil erosion and increasing moisture on farms.

\section{Objectives of the study}

- To identify indigenous and introduced SWC practices

- To describe identified indigenous and introduced soil and water conservation practices

- To know socio-economic aspects of identified indigenous and introduced SWC Practices

- To document the identified practices for further reference

\section{Methodology}

\subsection{Description of study site}

Southern nations, nationalities and peoples region is one of nine regional states of Ethiopia located in south and south west part. Geographically, it is located in coordinates of $4^{0} 27^{\prime}$ and $8^{0} 30^{\prime} \mathrm{N}$ and $34^{0} 21^{\prime}$ and $39^{\circ} 11^{\prime} \mathrm{E}$ with altitude ranging from 376 to 4207 masl and with mean annual temperature ranging from $15^{\circ} \mathrm{c}$ to $30^{\circ} \mathrm{c}(\mathrm{BoSp}, 2004)$. Wera Zuria, Hawassa zuria and Yirgachafe districts are located in the three central zones of south nations, nationalities and peoples of the region. Geographically, the districts are located in $7.4933^{\circ} \mathrm{N}$ and $38.1900^{\circ} \mathrm{E}$, $07^{0} 05.233^{\prime} \mathrm{N}$ and $038^{0} 21.688 \mathrm{E}, 38.19042 \mathrm{~N}$ and $6.13628 \mathrm{E}$ respectively. The agro ecologies of Wera zuria, Hawassa zuria and yirgachafe districts are categorized in mid land, dry mid land, and highland respectively. The rainfall pattern of the three districts is Bimodal with minimum rain at dry season and high rainfall in main rain season 


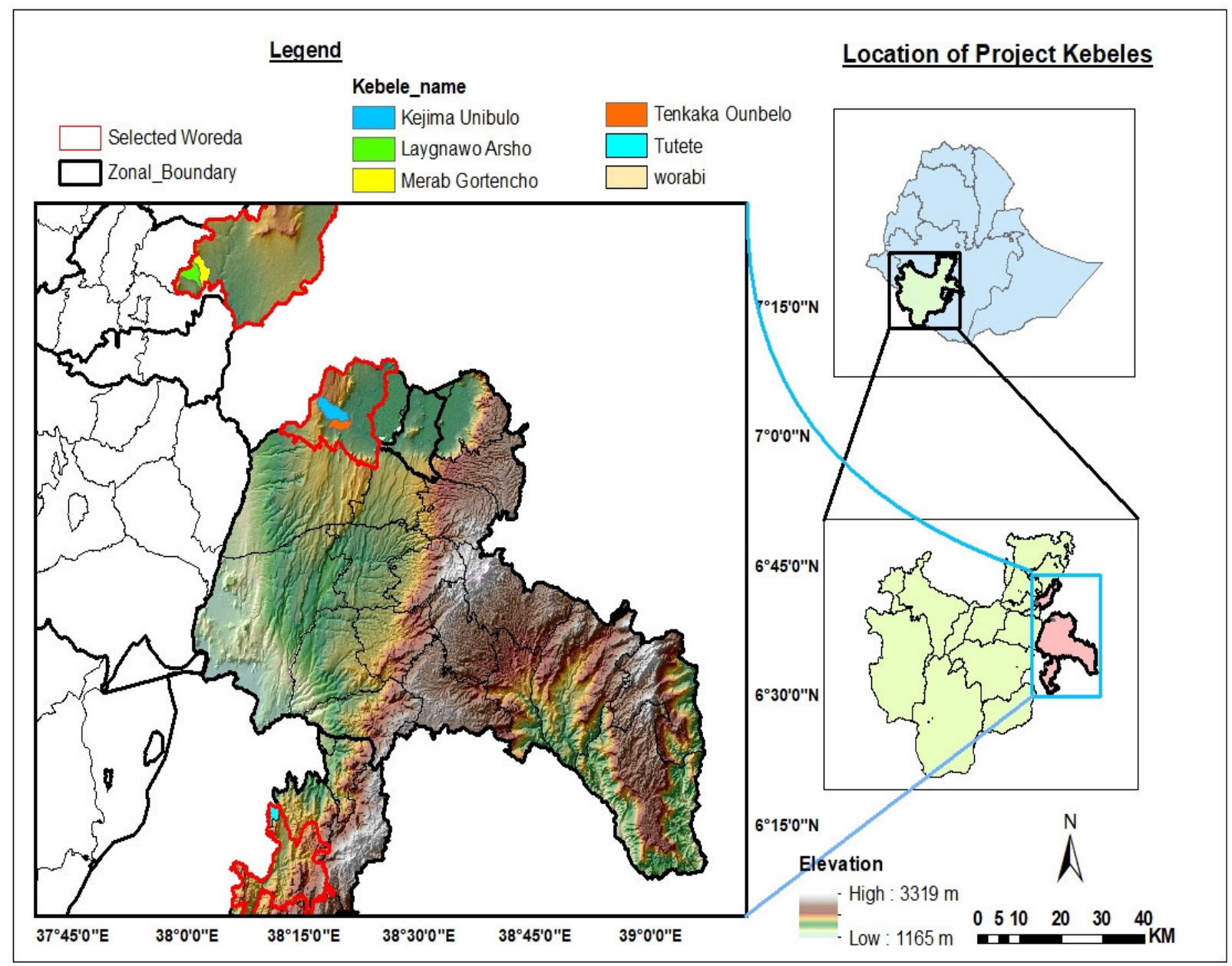

Figure 1: map of study area

\subsection{Data sources and collection methods.}

Data were collected from primary and secondary data sources. Primary data were collected from selected farmers of each kebele. Focus group discussions were also made with woreda's farm and natural resource management office to identify the SWC practices. Agricultural experts from different disciplines were participated on the discussion. Transect walk was also made to identify and describe different indigenous and introduced practices of selected kebeles. Secondary data were collected from regional, zonal and woreda's farm and natural resource management offices, and different literatures.

\subsection{Socio economic aspects of sampled population.}

\subsubsection{Sex and marital status of households}

Out of 60 sampled households from three districts $88.6 \%$ were male headed and $11.4 \%$ were female headed. Regarding to marital status $90.6 \%$ were married, $3.1 \%$ single and 6.3\% were widowed (Source, survey data 2018).

\subsubsection{Age, Education level and family size of respondents}

Regarding age and education level of respondents, the minimum age of respondents was twenty five and the maximum age was sixty three (63). The mean age of respondents was 39.7 years with the standard deviation of 7.67. Regarding to education level of respondents $46.7 \%$ have reading ability only; $50 \%$ of them have both reading and writing ability. Finally, 3.3\% cannot have both writing and reading skill. Regarding to the maximum number of family members per household are twelve and the minimum are five. 
Table 1: Distribution of respondents by age and education level

\begin{tabular}{|l|l|l|l|l|}
\hline Variables & Minimum & Maximum & Mean & Std. deviation \\
\hline Age & 25 & 63 & 39.7 & 7.67 \\
\hline Education level & 0 & 12 & 6.4 & 2.68 \\
\hline Family size & 5 & 12 & 7.22 & 1.89 \\
\hline
\end{tabular}

Source: Survey data, 2019

\subsubsection{Land holding condition of respondents}

The mean land holding of sampled households was 1.21 hectare with the maximum of 2.88 hectare and minimum of 0.25 hectare. From the total land holding of households 0.20 to 2.50 hectare was covered by crops(cultivated land), 0.01 to 1.50 hectare was grazing land and 0.13 to 1.50 hectare was cultivable land.

Table 2: Distribution of respondent's landholding by cultivated land, grazing land and cultivable land.

\begin{tabular}{|l|l|l|l|l|}
\hline Variables & Minimum & Maximum & Mean & Std.deviation \\
\hline Cultivated/crop/ land coverage(ha) & 0.20 & 2.50 & 0.87 & 0.54 \\
\hline Grazing land coverage(ha) & 0.01 & 1.50 & 0.30 & 0.27 \\
\hline Cultivable land coverage(ha) & 0.13 & 1.50 & 0.46 & 3.39 \\
\hline
\end{tabular}

Source: survey data 2019.

\subsubsection{Income source of sampled households}

The average percent share of household income from livestock, crop and off-farm activity was $18.44 \%, 73.86 \%$ and $7.7 \%$ respectively. The average land coverage by annual crops was 0.74 hectare with the maximum coverage of 2.50 and minimum coverage of 0.20 hectare. From cultivated land $45.15 \%$ was covered by annual crops.

\section{Agro-climatic pattern of each sampled districts}

\subsection{The rainfall pattern of wera district with respect to months of year.}

Farmers of the district produce agricultural crops two rounds per year; namely Belg and Meher production seasons. In average the district receives medium to low rainfall in September and October months; no rainfall at the district faces in November, December, January, February and march months; medium up to low rainfall in April, may and June months. Maximum rainfall at July and August months.(Source, 2018 survey data).

\subsection{The rainfall pattern of Hawassa zuria district with respect to months of year.}

There are two agricultural production seasons in the district namely; Meher and Belg production seasons. The area receives minimum rainfall at September and October. no rainfall at November, December, January, February and March months. low to medium rainfall in April and may months. Maximum rainfall in June, July and August months (Source: survey data, 2019).

\subsection{The rainfall pattern of Yirgachafe district with respect to months of year.}

Similarly, with wera zuria and Hawassa zuria districts yigachafe district also have two crop production seasons per year. Rainfall at yigachafe district starts at march and ends at November. The area receives high Rainfall at September, October, and November months; Minimum rainfall at April, May, June, July and August months; no rainfall at December, January February and March months (Source: Yirgachafe Woreda farm and natural resource management office, 2018).

\section{Major agricultural crops and their Adaptation practice for erosion control at selected districts.}

The three districts were potential areas of crop production. Some of the common crops identified per district are listed below: Teff, maize, wheat, pepper, sorghum, haricot bean, chat cabbage, finger millet (Dagussa) are common crops producing at Wera Zuria district. In other way haricot bean, maize, coffee, inset and pepper are common crops mostly producing at Hawassa Zuria District. Finally, in the case of Yirgachafe district; Barley, Wheat, Pea, Cabbage, Haricot bean, teff and sweat potato are the most commonly producing agricultural crops. Farmers practice different adaptation mechanisms for erosion control when the rain fall distribution of the area's were maximum or minimum. Some of them are: the practice of early sowing during scare rainfall season, Irrigation practices during rainfall scarcity, use open and close ended tied ridges to conserve water during minimum rainfall, use of cut of drain during excess water, contour terracing, physical soil and water conservation bunds, planting of different plants like: Sugar cane, grass, banana and enset at erosion expected positions (Source: Survey data, 2019). 


\section{Cropping system and its function at selected districts}

Cropping systems like mono cropping and intercropping area were the most familiar cropping systems practiced at three districts. Maize and common bean intercropping system was the dominant one at three districts. The practice of rotational cropping system was common at two districts specially Wera Zuria and Yirgachafe Districts. Majority of land at Yirgachafe District were covered by Agro forestry. Chat with maize production system was dominant in Wera Zuria district. Similarly, there was a practice of coffee and maize Agro forestry system at Hawassa Zuria district. According to the farmers perception there different functions for different cropping systems, for example Intercropping, agro forestry systems can: provide better production, reduce nutrient competition between crops, increase soil fertility and disease control, etc. Crop rotation system results with increased yield, disease reduction, improved soil fertility, etc. Finally, agro forestry system can provide multibenefit from small plot of land, reduces nutrient competition, improve soil properties and improves land sustainability.

\section{Soil Erosion occurrence and mechanisms to know erosion prevalence on the land}

All respondents perceived that there was a problem of soil erosion on their land. According to their response, erosion occurs when there was maximum rainfall at summer season and heavy wind intensity at dry season. In other way soil erosion can occur during dry season when the wind condition of the area became heavy. Farmers have their own mechanism to know whether soil erosion was available or not. Some of the mechanisms were; by observing the soil structure, when rocky and stony like structures starts visible on the land, when the root part of the plant starts to be visible, when crop yield reduced, when top soil removed physically, when small rills starts to be formed, when there was displacement of crops/seed from farm field.

\section{Common indigenous soil and water conservation practices.}

Indigenous soil and water conservation practices are traditional or innate soil and water conservation techniques farmers use to control soil erosion. Apart from the exotic soil and water conservation techniques, indigenous soil and water conservation activities have been implemented by individual farmers for the aim of mitigating soil erosion, conserving soil moisture and increasing soil fertility at household farm level. Indigenous SWC practices of the study areas are described as follows:-

\section{Contour farming}

In a sense contour farming is the farming practice which is important to conserve soil. The practice was applicable at the three districts indigenously by farming the land horizontally along the contour at sloppy lands. In soil conservation point of view the farming system was practiced in order to increase soil infiltration rate, to manage slope difference, to minimize runoff velocity and to harvest water on furrows. Source: Survey data, 2019.

\section{Manure/compost application}

Collection of Animals dung like cattle's, goats, horses, donkey and sheep near the farmer's house was common at the three districts. They use collected animal dung on cropping lands as an organic fertilizer. Some farmers at Layigna Arisho, Kajima Umbullo and Tuttiti kebeles collects green plant remaining, ash, remains of animal food and garbage collectively to use on crop lands. The practice was applicable indigenously because it was easy to do, increase soil fertility, increase crop production and better top soil resistance against erosion. Source: Survey data, 2019.

\section{Mulching}

The practice of covering soil surface by stubbles(stubble mulching), plant residues and plant remains/straw was common at Layigna Arisho, Kajima Umbullo, Worabi, Tutitti and Tankaka Umbullo Kebeles. According to the farmers perception the practice Increase soil infiltration rate, improves soil property, conserve and retain water, reduces raindrop effect on soil. Source: survey data, 2019.

\section{Tree planting}

This system was practiced at all kebeles of the study area. Farmers plant different provenances of trees on abandoned, grazing or common lands to rehabilitate the area. In other was they also plant trees on sloppy lands to reduce runoff velocity and stabilize the lands. Source: survey data, 2019.

\section{Enset, Banana and Sugarcane planting}

Planting of Enset, Banana and Sugarcane is common at the study areas, especially at Tanakaka Umbullo, Kajima Umbullo, Tutitti and worabi kebeles. Farmers of those kebeles plant those crops at eroding direction to minimize runoff velocity and stabilize the land. The farmers at Tanakaka Umbullo, Kajima Umbullo also uses the crops for gully rehabilitation and plant those crops at the top of crop land to protect the land from erosion. Source: survey data, 2019.

\section{Crop rotation}

According to the respondents crop rotation/alternative cropping system was common at the three study areas. The farmers of the areas could plant one crop type at specified season then the other crop type at the next cropping season of the year. At Layigna Arisho and Mirab Gortanicho kebeles they could plant maize, common bean and 
potato solely in belg season, then in the same land they could plant potato, maize/sorghum and wheat in mehar season respectively. Similarly, at Kajima Umbullo and Tankaka Umbullo kebeles farmers could plant maize crop at specified plot of land in belg season then they could plant common bean in meher season at the same plot of land. Farmers of the study areas practice this cropping system indigenously; to increase crop to grain yield, to reduce disease, to minimize soil degradation and improves soil quality. (Source: survey data: 2019).

\section{Intercropping}

Cropping two different annual crops on the same plot of land in the same cropping season was common at the three districts. For example: combined planting of maize with common bean, sorghum with common bean on the same plot of land were familiar at kajima umbullo, tankaka umbullo, layigna arisho kebeles and M/gortanicho kebeles. Farmers of Tuttiti and Worabi kebeles practiced planting of maize with pea, maize with bean on the same plot of land. They practiced this cropping system indigenously; to get two benefits/outputs from specific land at the same season, to reduce nutrient competition between crops, to reduce disease, to improve soil properties and to protect soil quality. (Source: survey data: 2019).

\section{Agro forestry}

Farmers of the study areas practiced the planting of annual crops inside perennial trees on specified plot of land. Especially, At Tuttiti and Worabi kebeles the were the areas from well known agro forestry system practiced areas of the region. They plant enset, maize, pea, bean, barley, wheat and others inside perennial trees. According to the respondent's attitude the farming system were practiced; to provide two or more outputs, to reduce nutrient competition, to reduce disease, to improve soil nutrient content and to increase land productivity. (Source: survey data: 2019).

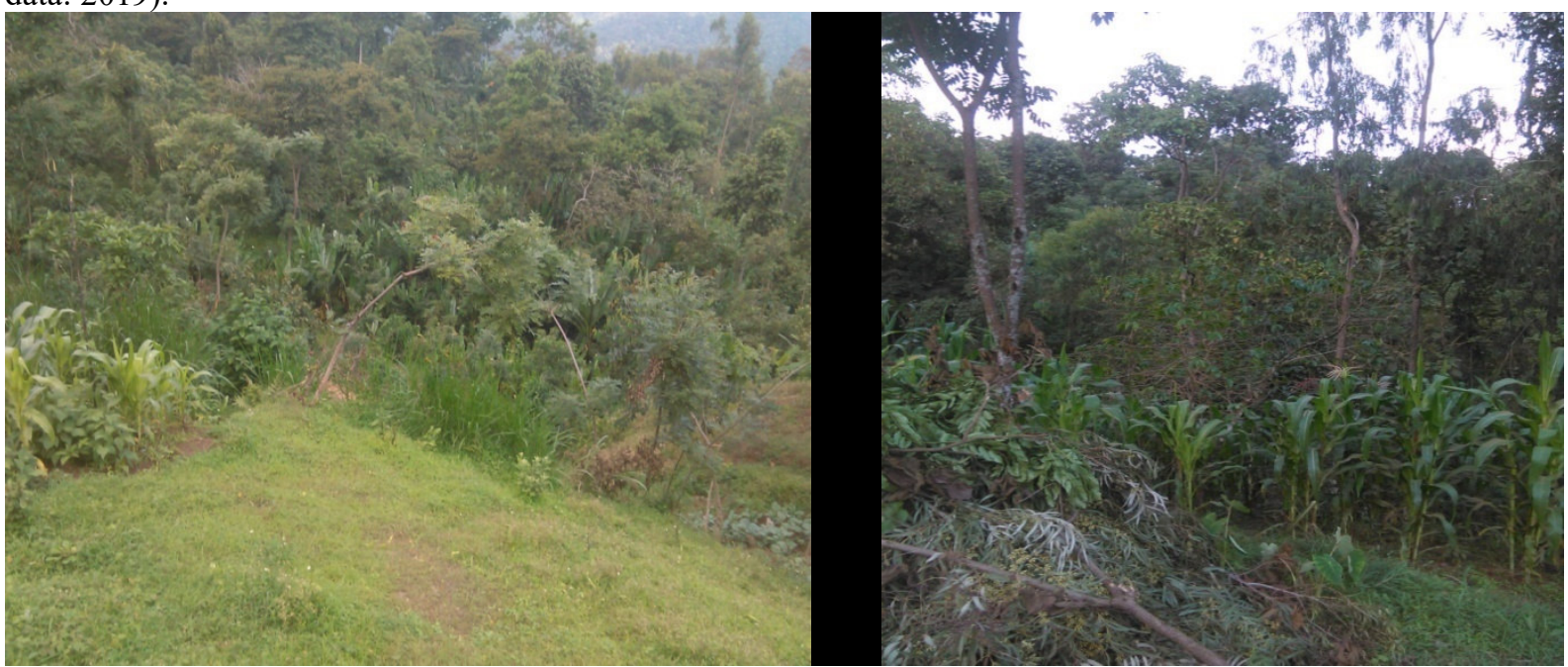

Figure 2: Agro-forestry practice at Tuttiti kebele, yirgachafe district

\section{Traditional pit}

This practice implies indigenous preparation of different water harvesting small traditional pits inside the coffee farm. At Tuttiti and Worabi kebeles the preparation of small traditional pits which harvest in-situ water inside coffee farm was common. The farmers of the area practiced this system due to the following purposes; to increases soil infiltration rate, conserve water, increase ground water potential and to improve water availability for crops like coffee. (Source: survey data: 2019).

\section{Fallowing}

When the production capacity of the land starts decline from year to year, the farmers could fallow their agricultural land for one or more years indigenously. This practice was common at Tuttiti and Worabi kebeles. Farmers of the areas practice this system due to the following purposes; to prevent disease, to improve soil nutrients content, to improve soil sustainability and increases land productivity. (Source: survey data: 2019).

\section{Cut off drain}

This system implies the practice of preparing of water flow furrow to remove excess water from the farm field. Farmers of the of Tuttiti, Worabi, Layigna Arisho and M/gortanicho kebeles practiced this technique indigenously to remove excess water from their farm field. According to the respondents, they practiced the technique because; it helps for easily remove excess water from their farm field without affecting the soil and crop, it protects the land from serious erosion by safe removal of water, it protect the land from water logging and siltation problems.(Source: survey data: 2019). 
Table 3: Summary of identified indigenous soil and water conservation practices of the study areas.

\begin{tabular}{|c|c|c|c|c|c|c|c|}
\hline No. & $\begin{array}{l}\text { Name of SWC } \\
\text { practices }\end{array}$ & Kebeles & Local name & $\begin{array}{l}\text { Implementing } \\
\text { system }\end{array}$ & Function of practice & $\begin{array}{l}\text { SWC } \\
\text { category }\end{array}$ & $\begin{array}{l}\text { Implementing } \\
\text { season }\end{array}$ \\
\hline 1. & $\begin{array}{l}\text { Napier grass } \\
\text { planting }\end{array}$ & $\begin{array}{l}\text { Layigna Arisho } \\
\text { and } \\
\text { M/gortanicho }\end{array}$ & Duffa kaasu & $\begin{array}{l}\text { Planting of Duffa } \\
\text { grass at water flow } \\
\text { direction. }\end{array}$ & $\begin{array}{l}\text { Reduces rain drops } \\
\text { impact on soil by } \\
\text { interception } \\
\text { Controls soil erosion by } \\
\text { conserving water and } \\
\text { reducing r runoff } \\
\text { velocity. }\end{array}$ & $\begin{array}{l}\text { Biological } \\
\text { SWC } \\
\text { practice }\end{array}$ & $\begin{array}{l}\text { At wet/ summer } \\
\text { season. }\end{array}$ \\
\hline \multirow[t]{2}{*}{2.} & \multirow[t]{2}{*}{$\begin{array}{l}\text { Banana, enset } \\
\text { and sugarcane } \\
\text { planting. }\end{array}$} & $\begin{array}{l}\text { Layigna Arisho } \\
\text { and } \\
\mathrm{M} / \text { gortanicho }\end{array}$ & $\begin{array}{l}\text { Muza, weesita } \\
\text { shonkora Kaasu }\end{array}$ & \multirow{2}{*}{$\begin{array}{l}\text { Planting of banana } \\
\text { plant at erosion } \\
\text { prone or runoff flow } \\
\text { areas. }\end{array}$} & \multirow{2}{*}{$\begin{array}{l}\text { Used as a barrier for } \\
\text { eroding water flow. } \\
\text { Reduce runoff flow } \\
\text { velocity. } \\
\text { Stabilize the land. }\end{array}$} & \multirow[t]{2}{*}{$\begin{array}{l}\text { Biological } \\
\text { SWC } \\
\text { practice. }\end{array}$} & \multirow[t]{2}{*}{$\begin{array}{l}\text { Wet/Summer } \\
\text { season. }\end{array}$} \\
\hline & & $\begin{array}{l}\text { Tankaka } \\
\text { Umbullo and } \\
\text { Kajima } \\
\text { Umbullo } \\
\end{array}$ & $\begin{array}{l}\text { Shonkora,Muzena } \\
\text { Weese Kaasha }\end{array}$ & & & & \\
\hline 3. & Manuring & $\begin{array}{l}\text { Layigna Arisho } \\
\text { and } \\
\text { M/gortanicho. }\end{array}$ & Shalla ujju & $\begin{array}{l}\text { Applying organic } \\
\text { manure on farm } \\
\text { lands. }\end{array}$ & $\begin{array}{l}\text { Retain water } \\
\text { Improve soil nutrient } \\
\text { and increase soil } \\
\text { productivity. } \\
\text { Increase infiltration rate. }\end{array}$ & $\begin{array}{l}\text { Agronomic } \\
\text { SWC } \\
\text { practice. }\end{array}$ & $\begin{array}{l}\text { Wet and dry } \\
\text { seasons. Before } \\
\text { crop planting. }\end{array}$ \\
\hline \multirow[t]{3}{*}{4.} & \multirow[t]{3}{*}{$\begin{array}{l}\text { Contour } \\
\text { farming }\end{array}$} & $\begin{array}{l}\text { Layigna Arisho } \\
\text { and } \\
\text { M/gortanicho }\end{array}$ & Zaabe hoguta & \multirow{3}{*}{$\begin{array}{l}\text { Farming/ploughing } \\
\text { the land across the } \\
\text { slope along the } \\
\text { contour. }\end{array}$} & \multirow{3}{*}{$\begin{array}{l}\text { Reduce erosion rate and } \\
\text { run off velocity. } \\
\text { Conserve water } \\
\text { Facilitate } \\
\text { infiltration rate. } \\
\begin{array}{l}\text { Manage } \\
\text { difference. }\end{array}\end{array}$} & \multirow{3}{*}{$\begin{array}{l}\text { Agronomic } \\
\text { SWC } \\
\text { practice. }\end{array}$} & \multirow[t]{3}{*}{$\begin{array}{l}\text { During farming } \\
\text { season. }\end{array}$} \\
\hline & & $\begin{array}{l}\text { Tankaka } \\
\text { Umbullo and } \\
\text { Kajima } \\
\text { Umbullo } \\
\end{array}$ & Hawitto Loosa & & & & \\
\hline & & $\begin{array}{l}\text { Tuttiti and } \\
\text { Worabi. }\end{array}$ & & & & & \\
\hline \multirow[t]{3}{*}{5.} & \multirow[t]{3}{*}{ Mulching } & Layigna Arisho & $\begin{array}{l}\text { Bonxa te galaba } \\
\text { uju(Guzguaz) }\end{array}$ & \multirow{3}{*}{$\begin{array}{l}\text { Leaving different } \\
\text { crop } \\
\text { residues/remains on } \\
\text { farm lands. }\end{array}$} & \multirow{3}{*}{$\begin{array}{l}\text { Increase soil infiltration } \\
\text { rate } \\
\text { Improves soil property. } \\
\text { Conserve and retain } \\
\text { water. } \\
\text { Reduces raindrop effect } \\
\text { on soil. }\end{array}$} & \multirow{3}{*}{$\begin{array}{l}\text { Agronomic } \\
\text { SWC } \\
\text { practice. }\end{array}$} & \multirow{3}{*}{$\begin{array}{l}\text { Wet and dry } \\
\text { season }\end{array}$} \\
\hline & & $\begin{array}{l}\text { Kajima } \\
\text { Umbullo and } \\
\text { Tankaka } \\
\text { Umbullo. } \\
\end{array}$ & Daro Diba & & & & \\
\hline & & $\begin{array}{l}\text { Worabi and } \\
\text { Tutitti }\end{array}$ & & & & & \\
\hline 6. & $\begin{array}{l}\text { Brush wood } \\
\text { check dam }\end{array}$ & $\begin{array}{l}\text { Layigna Arisho } \\
\text { and } \\
\text { M/gortanicho. }\end{array}$ & Kitir/haqi ribrabuta & $\begin{array}{l}\text { Placing different } \\
\text { stem parts of tree } \\
\text { cut inside gullies } \\
\text { and rills. }\end{array}$ & $\begin{array}{l}\text { Used as a barrier for } \\
\text { water flow on the gully. } \\
\text { Reduce runoff velocity } \\
\text { and others. }\end{array}$ & $\begin{array}{l}\text { Mechanical } \\
\text { SWC } \\
\text { practice. }\end{array}$ & Dry/off season. \\
\hline \multirow[t]{3}{*}{7.} & \multirow[t]{3}{*}{ Intercropping } & $\begin{array}{l}\text { Layigna Arisho } \\
\text { and } \\
\text { M/gortanicho. }\end{array}$ & Lammuta & \multirow{3}{*}{$\begin{array}{l}\text { Cropping two } \\
\text { different annual } \\
\text { crops on the same } \\
\text { plot of land at the } \\
\text { same season. } \\
\text { Example: maize } \\
\text { and common bean. }\end{array}$} & \multirow{3}{*}{$\begin{array}{l}\text { Two benefits/outputs at } \\
\text { the same season. } \\
\text { Reduced nutrient } \\
\text { competition between } \\
\text { two different crops. } \\
\text { Reduced disease. } \\
\text { Improves } \\
\text { properties. } \\
\text { Protect soil quality. }\end{array}$} & \multirow{3}{*}{$\begin{array}{l}\text { Agronomic } \\
\text { SWC } \\
\text { practice }\end{array}$} & \multirow[t]{3}{*}{$\begin{array}{l}\text { Wet/Planting } \\
\text { season }\end{array}$} \\
\hline & & $\begin{array}{l}\text { Kajima } \\
\text { Umbullo and } \\
\text { Tankaka } \\
\text { Umbullo. } \\
\end{array}$ & Karsiise kaasa. & & & & \\
\hline & & $\begin{array}{l}\text { Worabi and } \\
\text { Tutitti }\end{array}$ & & & & & \\
\hline \multirow[t]{3}{*}{8.} & \multirow[t]{3}{*}{ Crop rotation } & $\begin{array}{l}\text { Layigna Arisho } \\
\text { and } \\
\text { M/gortanicho. }\end{array}$ & Doransu. & \multirow{3}{*}{$\begin{array}{l}\text { Cropping of one } \\
\text { crop at one season } \\
\text { and other at the next } \\
\text { season at the same } \\
\text { plot of land. }\end{array}$} & \multirow{3}{*}{$\begin{array}{l}\text { Reduces disease. } \\
\text { Increases crop yield. } \\
\text { Improves soil quality. }\end{array}$} & \multirow{3}{*}{$\begin{array}{l}\text { Agronomic } \\
\text { SWC } \\
\text { practice. }\end{array}$} & \multirow[t]{3}{*}{ Planting season. } \\
\hline & & $\begin{array}{l}\text { Kajima } \\
\text { Umbullo and } \\
\text { Tankaka } \\
\text { Umbullo. } \\
\end{array}$ & Wita Soran Wita & & & & \\
\hline & & $\begin{array}{l}\text { Worabi and } \\
\text { Tutitti }\end{array}$ & $\begin{array}{l}\text { Eyekayayaru } \\
\text { Mazirat. }\end{array}$ & & & & \\
\hline 9. & $\begin{array}{l}\text { Plantation of } \\
\text { Sisal (Agave } \\
\text { sisalana } \\
\text { Perrine). }\end{array}$ & $\begin{array}{l}\text { Kajima } \\
\text { Umbullo and } \\
\text { Tankaka } \\
\text { Umbullo. } \\
\end{array}$ & Argissa/Kanche & $\begin{array}{l}\text { Planting of sisal at } \\
\text { erosion prone areas. }\end{array}$ & $\begin{array}{l}\text { Stabilize the land. } \\
\text { Reduce runoff velocity. }\end{array}$ & $\begin{array}{l}\text { Biological } \\
\text { SWC } \\
\text { practice. }\end{array}$ & $\begin{array}{l}\text { Wet/summer } \\
\text { season. }\end{array}$ \\
\hline \multirow[t]{3}{*}{10.} & \multirow[t]{3}{*}{ Tree planting } & $\begin{array}{l}\text { Layigna Arisho } \\
\text { and } \\
\text { M/gortanicho. }\end{array}$ & Haqqa kaasu & \multirow{3}{*}{\begin{tabular}{lr}
\multicolumn{3}{l}{ Planting of different } \\
tree species on \\
sloppy \\
degraded lands. and
\end{tabular}} & \multirow{3}{*}{$\begin{array}{l}\text { Stabilize the land. } \\
\text { Rehabilitate the area. } \\
\text { Reduce runoff velocity. } \\
\text { Improves soil } \\
\text { errodiblity. }\end{array}$} & $\begin{array}{l}\text { Biological } \\
\text { SWC }\end{array}$ & $\begin{array}{l}\text { Wet/summer } \\
\text { season }\end{array}$ \\
\hline & & $\begin{array}{l}\text { Kajima } \\
\text { Umbullo and } \\
\text { Tankaka } \\
\text { Umbullo. } \\
\end{array}$ & Haqqe Kayisa & & & practice. & \\
\hline & & $\begin{array}{l}\text { Worabi and } \\
\text { Tutitti }\end{array}$ & & & & & \\
\hline
\end{tabular}




\begin{tabular}{|c|c|c|c|c|c|c|c|}
\hline No. & $\begin{array}{l}\text { Name of SWC } \\
\text { practices }\end{array}$ & Kebeles & Local name & $\begin{array}{l}\text { Implementing } \\
\text { system }\end{array}$ & Function of practice & $\begin{array}{l}\text { SWC } \\
\text { category }\end{array}$ & $\begin{array}{l}\text { Implementing } \\
\text { season }\end{array}$ \\
\hline 11. & Agro forestry & $\begin{array}{l}\text { Worabi and } \\
\text { Tutitti }\end{array}$ & Timir Dan & $\begin{array}{l}\text { Planting of different } \\
\text { annual crops inside } \\
\text { the perennials. } \\
\text { Example: maize } \\
\text { and coffee. } \\
\begin{array}{l}\text { Maize and warka } \\
\text { tree. }\end{array}\end{array}$ & $\begin{array}{llr}\text { Provide two } & \text { or more } \\
\text { outputs. } & & \\
\text { Reduce } & \text { nutrient } \\
\text { competition. } & \\
\text { Reduce disease } & \\
\text { Improve soil } & \text { nutrient } \\
\text { content. } & & \\
\text { Increase } & \text { land } \\
\text { productivity. } & \end{array}$ & $\begin{array}{l}\text { Biological } \\
\text { SWC } \\
\text { practice. }\end{array}$ & $\begin{array}{l}\text { Wet/summer } \\
\text { season }\end{array}$ \\
\hline 12. & Traditional pit. & $\begin{array}{l}\text { Worabi and } \\
\text { Tutitti }\end{array}$ & Gudguad & $\begin{array}{lr}\text { Preparation } & \text { of } \\
\text { different } & \text { water } \\
\text { harvesting } & \text { small } \\
\text { traditional } & \text { pits } \\
\text { inside the } & \text { coffee } \\
\text { farm. } & \end{array}$ & 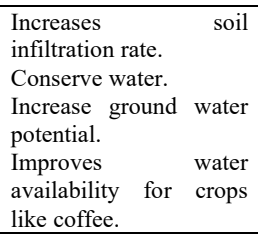 & $\begin{array}{l}\text { Physical } \\
\text { SWC } \\
\text { practice. }\end{array}$ & All seasons. \\
\hline \multirow[t]{2}{*}{13.} & \multirow[t]{2}{*}{ Cut off drain. } & $\begin{array}{l}\text { Layigna Arisho } \\
\text { and } \\
\text { M/gortanicho }\end{array}$ & Zoofi Boyita. & \multirow[t]{2}{*}{$\begin{array}{l}\text { Farmers prepare } \\
\text { drainage way/cut } \\
\text { off drain to remove } \\
\text { excess water from } \\
\text { farm field at sloppy } \\
\text { areas. }\end{array}$} & \multirow{2}{*}{$\begin{array}{l}\text { It helps for easily } \\
\text { removal of excess water } \\
\text { from the farm field } \\
\text { without affecting the } \\
\text { soil and crop. } \\
\text { It protects the land from } \\
\text { serious erosion by safe } \\
\text { removal of water. } \\
\text { It protect the land from } \\
\text { water logging and } \\
\text { siltation problems. }\end{array}$} & \multirow[t]{2}{*}{$\begin{array}{l}\text { Physical } \\
\text { SWC } \\
\text { practice. }\end{array}$} & \multirow[t]{2}{*}{$\begin{array}{l}\text { Summer/rainy } \\
\text { season. }\end{array}$} \\
\hline & & $\begin{array}{l}\text { Worabi and } \\
\text { Tutitti }\end{array}$ & Boyi & & & & \\
\hline 14. & Fallowing. & $\begin{array}{l}\text { Worabi and } \\
\text { Tutitti }\end{array}$ & Masadar & $\begin{array}{l}\text { Staying the land for } \\
\text { one or two years } \\
\text { without crop } \\
\text { production/farming. }\end{array}$ & \begin{tabular}{l}
\multicolumn{2}{l}{ Prevent disease. } \\
Improve soil structure \\
and nutrients. \\
Improves \\
sustainability. \\
$\begin{array}{l}\text { Increases } \\
\text { productivity. }\end{array}$
\end{tabular} & $\begin{array}{l}\text { Agronomic } \\
\text { SWC } \\
\text { practice }\end{array}$ & All seasons. \\
\hline
\end{tabular}

Source: survey data, 2019.

\section{Common introduced soil and water conservation practices at the study areas.}

Introduced soil and water conservation practices are modern practices gained by training or help of agricultural experts The practices may include physical/mechanical, Biological and Agronomic soil and water conservation measures (survey data, 2019). Introduced soil and water conservation techniques have been implemented by government organization particularly by the regional Bureau of Agriculture, starting from region to district level. Moreover, various nongovernmental organizations including bilateral and multi -lateral organizations have implemented soil and water conservation techniques in the highly degraded areas to halt the rapidly increasing land degradation specifically soil erosion.

Soil bund

According to the data collected from all study districts farm and natural resource development offices, soil bund was introduced to all kebeles of each district. Mainly this structure was constructed by public complain each year. It was done by designing and excavating a line between two points along the contour and throwing the excavated soil below the ditch. This structure was constructed on the lands with the slope of $3-30 \%$. It was constructed by $10 \mathrm{~m}$ length, $30-70 \mathrm{~cm}$ width, 30-60 cm depth, 20-25cm burm width, 40-60 embankment height and 30-50 $\mathrm{cm}$ embankment width. This was done; to conserve moisture, to increase soil infiltration rate, to reduce erosion by minimizing runoff velocity and harvesting water on the ditch. (Source: survey data: 2019). 


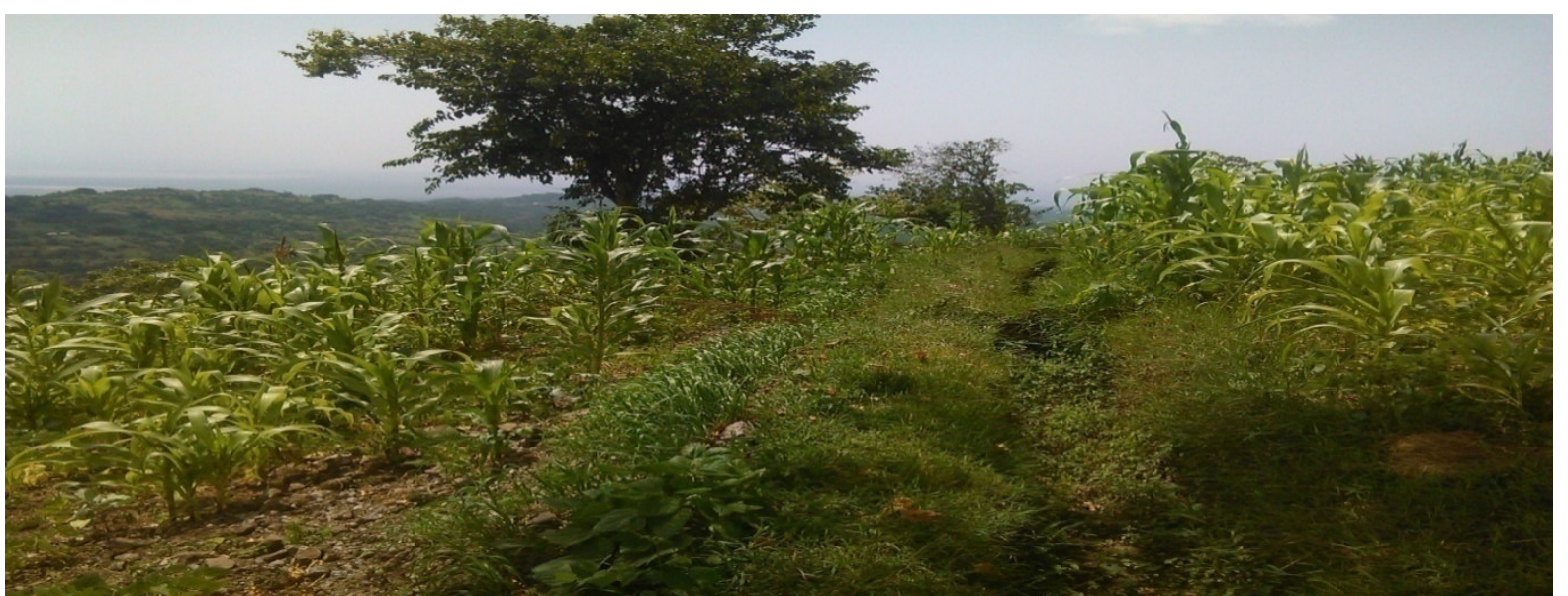

Figure 2: soil bund constructed and stabilized on farm lands at Tuttiti Kebele

Fanaju bund

This bund also was constructed on farm lands by watershed management public complain work. It was done by designing and excavating a line between two points along the contour and throwing the excavated soil above the ditch. This structure was constructed on the lands with the slope of 3-50\%. The dimensions were similar with soil bund that means it was $10 \mathrm{~m}$ length, $30-70 \mathrm{~cm}$ width, 30-60 cm depth, $20-25 \mathrm{~cm}$ burm width, $40-60$ embankment height and $30-50 \mathrm{~cm}$ embankment width. This was done; to conserve moisture, to increase soil infiltration rate, to reduce erosion by minimizing runoff velocity and harvesting water on the ditch. (Source: survey data: 2019).

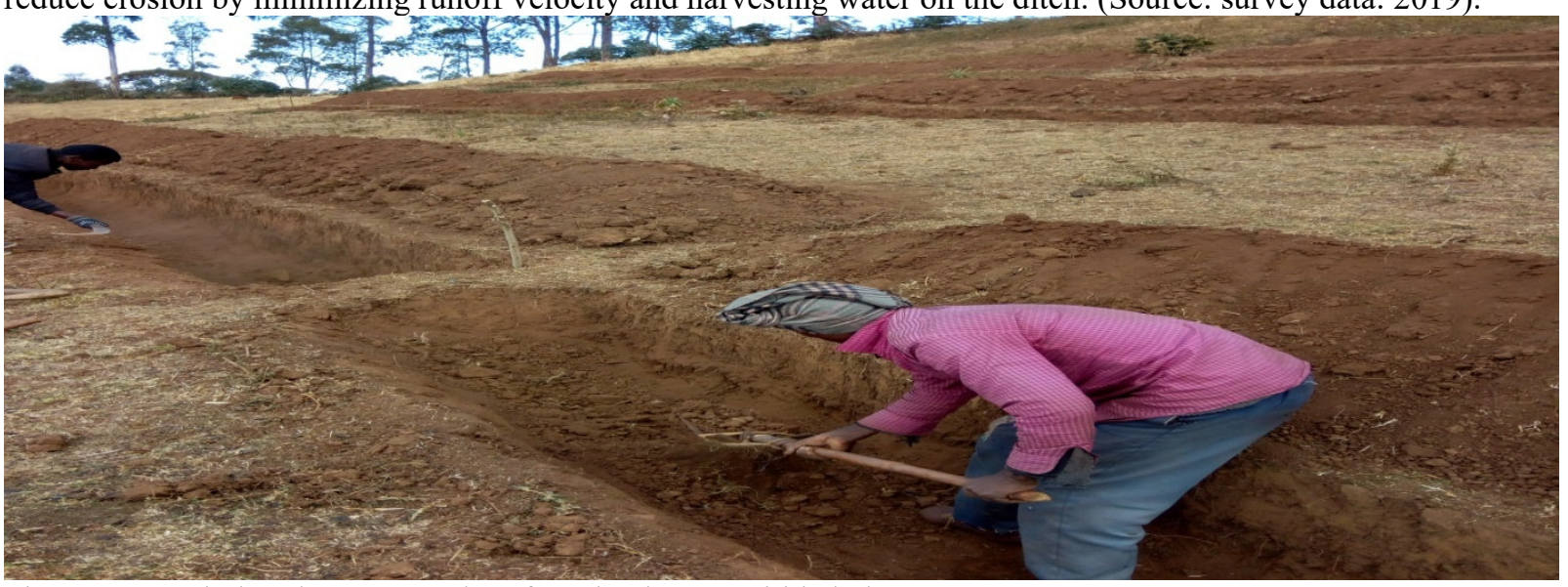

Figure 3: Fanaju bund constructed on farm lands at Tuttiti kebele

Trench bund

Trenches were constructed by public complain and by individual farmers. It was constructed along the contour. The lengths of trenches were not more than $2-5 \mathrm{~m}$ and the depth of each trench were not less than $50 \mathrm{~cm}$. At Tuttiti, Worabi and Layigna Arisho kebeles different tree species were planted to stabilize the bund and the area, but at some areas the planted trees were dried. This was done in order to conserve moisture conservation, to harvest runoff water, to rehabilitate degraded and closure areas, to increase ground water potential, to increase soil infiltration rate and improve crop water availability. (Source: survey data: 2019).

\section{Tied ridges}

There was a practice of preparing water conserving ditches with ties which connects the ditches. The practice was applied on maize and sorghum farm especially at Layigna Arisho and $\mathrm{M}$ /gortanicho kebeles. This was done to increase water availability for crop, to increase soil infiltration rate and conserve in-situ water. (Source: survey data: 2019).

\section{Sand filled check dam}

In some extent SWC technique was applied at Layigna Arisho, M/goritanicho, Tankaka Umbullo and Kajima unbullo to rehabilitate gullies. This practice was done by filling sacks with sand/soil and then constructing it horizontally as a barrier for runoff on the gully. It was done to control gully erosion and to use as barrier for run off on the gully. (Source: survey data: 2019). 

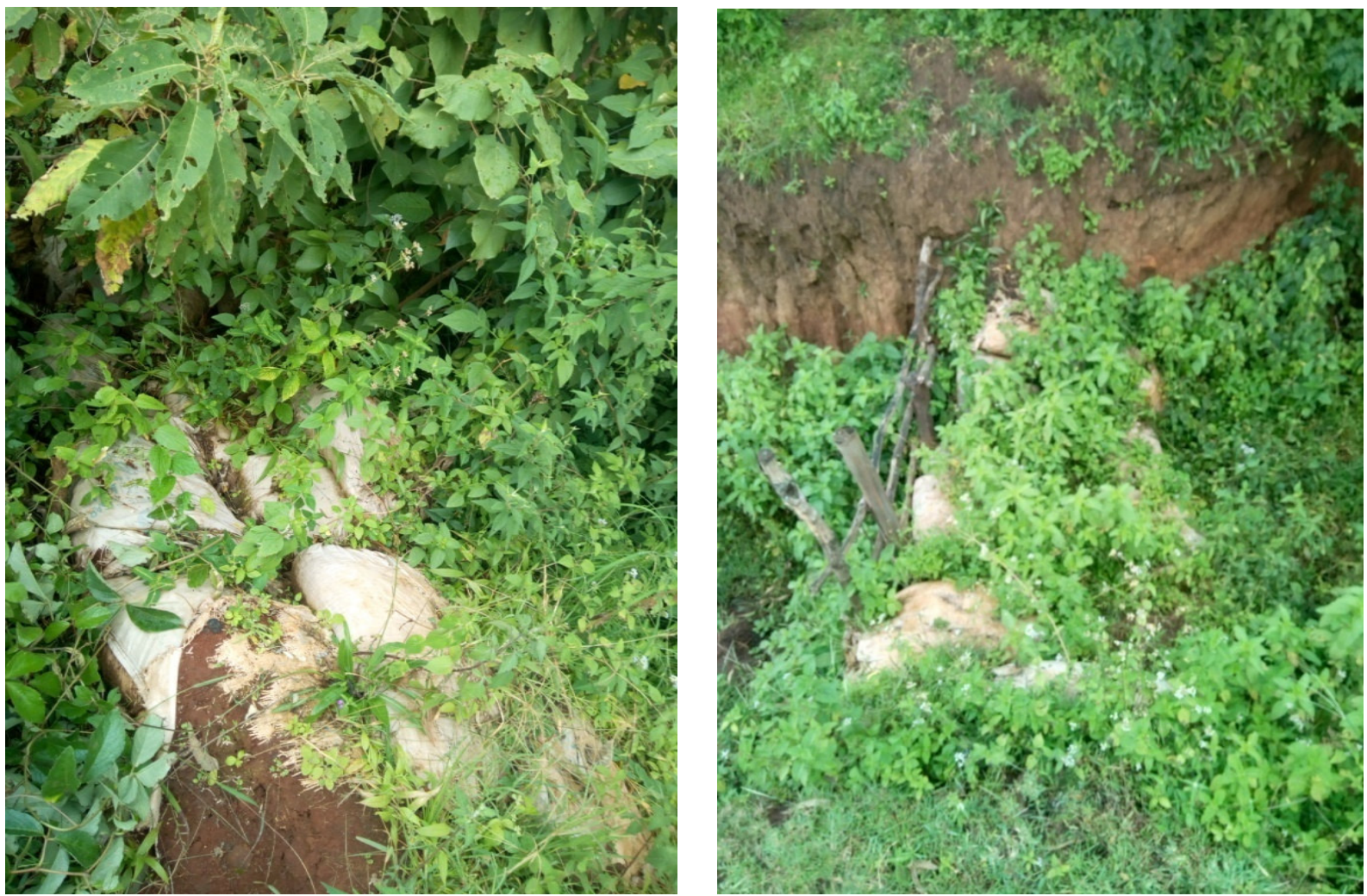

Figure 4: gully rehabilitation practice implemented at Layigna Arisho kebele by using sand filled sacks

\section{Gabion}

This gully control measure was applied at Layigna Arisho, Kajima umbullo and Tankaka umbullo kebeles to rehabilitate large gullies. It was constructed by using stone and gabion mesh horizontally on the gullies. The implementation of this practice was to rehabilitate large gullies, to reduce run off velocity and use as a barrier for runoff on the gully. (Source: survey data: 2019).
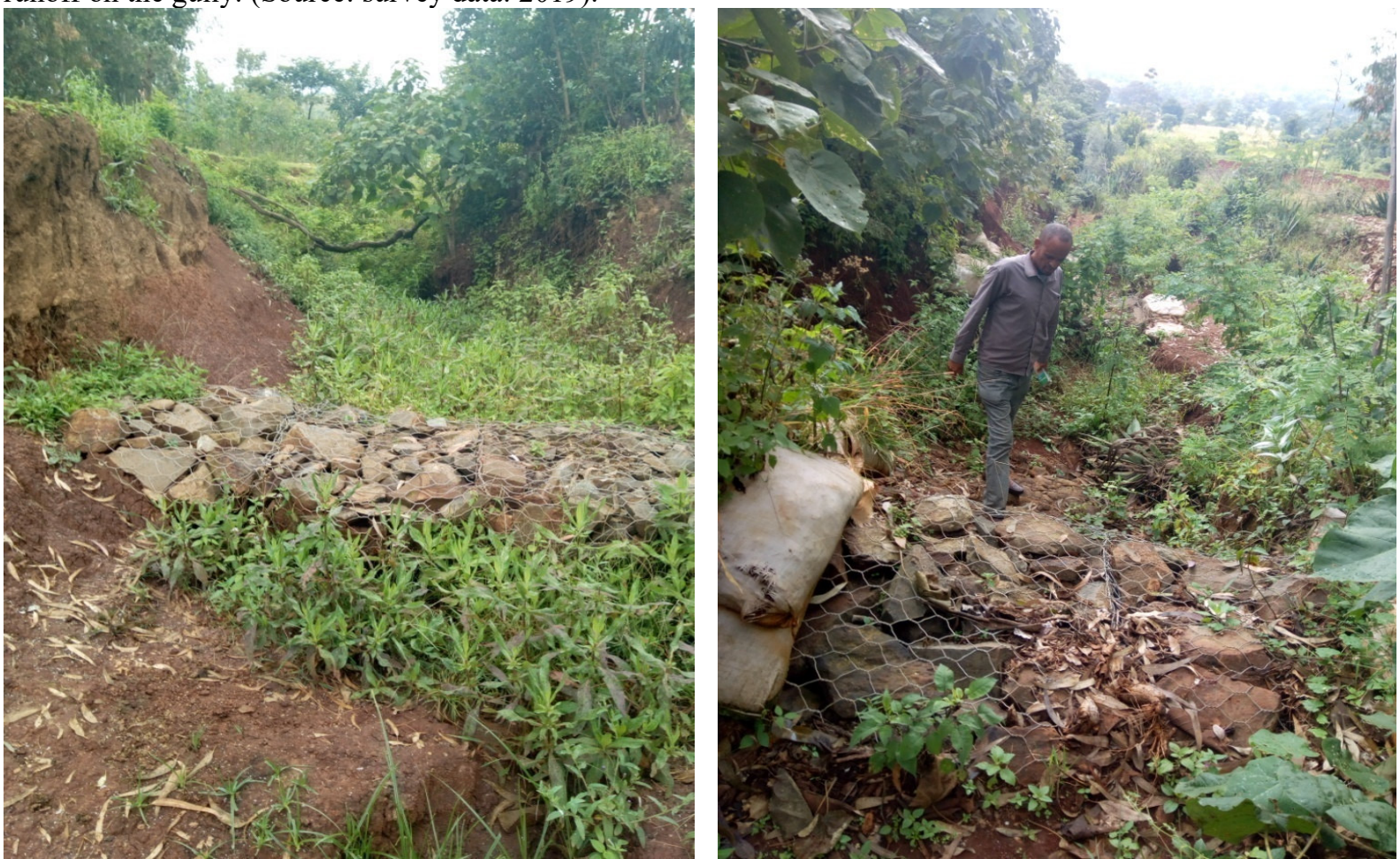

Figure 5: Gully rehabilitation practice at Layigna Arisho Kebele by using gabion

Farm pond and Improved pit

Farm pond implies the construction of water harvesting pond inside or near to farm field. In some extent this 
practice was applied at Layigna Arisho and M/gortanicho kebeles by government support. This was done to animal watering, irrigate crops at dry season and to reduce water scarcity. In other way, improved pit was practiced by excavating a pit with the specified size which means $50 \mathrm{~cm}$ width and $50 \mathrm{~cm}$ depth at Tuttiti and Worabi kebeles. It helps to improves crop water availability especially for coffee, conserve in-situ and flowing water. (Source: survey data: 2019).

\section{Microbezin and eyebrow bezin}

These Physical SWC practices were applied at Tankaka Umbullo and Kajima Umbullo kebeles. The structures were constructed in half moon shape along the contour, at communal lands and closure areas. These were done to conserve/harvest water, to improve water availability for tree planted on the structure, to reclaim degraded area.

(Source: survey data: 2019).

\section{Grass Strip}

Planting of grasses horizontally on farm lands along the contour was common at Kajima Umbullo kebele. Both elephant and desho grasses were used to plant grass strip on the farm land to control erosion. According to the respondents the practice was important to control soil erosion by reducing rain drops effect and reducing runoff velocity. In addition to erosion controlling effect it was good source of forage for animals. (Source: survey data: 2019).
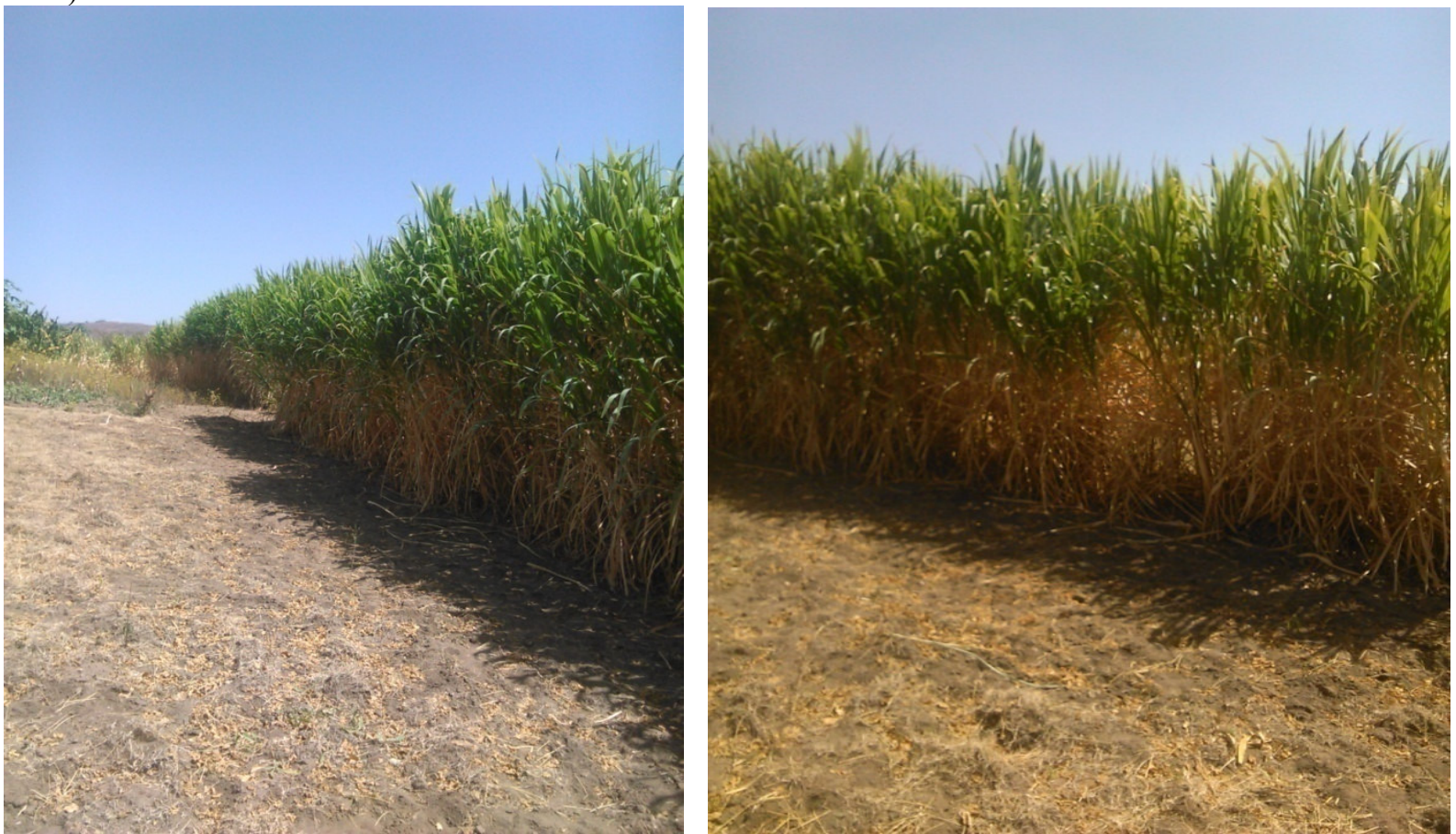

Figure 6: Elephant grass strips planted at tankaka umbullo kebele, Hawassa Zuria district.

Table 4: Summary of identified introduced soil and water conservation practices of the study areas.

\begin{tabular}{|c|c|c|c|c|c|c|c|c|}
\hline No. & $\begin{array}{l}\text { Name of } \\
\text { SWC } \\
\text { practice }\end{array}$ & Kebeles & $\begin{array}{l}\text { Local } \\
\text { name }\end{array}$ & $\begin{array}{l}\text { Implementing } \\
\text { system }\end{array}$ & Function & SWC cat & & $\begin{array}{l}\text { Implementing } \\
\text { season }\end{array}$ \\
\hline \multirow[t]{3}{*}{1.} & \multirow[t]{3}{*}{ Soil bund } & $\begin{array}{l}\text { Layigna } \\
\text { Arisho and } \\
\text { M/ } \\
\text { gortanicho. }\end{array}$ & Kaba & \multirow{3}{*}{$\begin{array}{lr}\text { It } & \text { was } \\
\text { constructed by } \\
\text { digging a line } \\
\text { between two } \\
\text { points which } \\
\text { have equal } \\
\text { elevation and } \\
\text { throwing the } \\
\text { excavated soil } \\
\text { below the } \\
\text { ditch. }\end{array}$} & \multirow{3}{*}{$\begin{array}{ll}\text { - } & \text { It helps to conserve } \\
\text { soil moisture. } \\
\text { Reduce erosion by } \\
\text { minimizing runoff } \\
\text { velocity and } \\
\text { harvesting water on } \\
\text { the ditch. } \\
\text { Improve infiltration } \\
\text { rate of soil. }\end{array}$} & \multirow[t]{3}{*}{$\begin{array}{l}\text { Physical } \\
\text { practice. }\end{array}$} & \multirow[t]{3}{*}{ SWC } & \multirow[t]{3}{*}{ Dry season } \\
\hline & & $\begin{array}{l}\text { Kajima } \\
\text { Umbullo } \\
\text { and } \\
\text { Tankaka } \\
\text { Umbullo. }\end{array}$ & Irkane & & & & & \\
\hline & & $\begin{array}{l}\text { Tuttiti and } \\
\text { worabi }\end{array}$ & Irkan & & & & & \\
\hline \multirow[t]{3}{*}{2.} & \multirow[t]{3}{*}{$\begin{array}{l}\text { Fanaju } \\
\text { bund }\end{array}$} & $\begin{array}{l}\text { Layigna } \\
\text { Arisho and } \\
\text { M/ } \\
\text { gortanicho }\end{array}$ & Kaba & \multirow{3}{*}{$\begin{array}{l}\text { It was } \\
\text { constructed } \\
\text { designing and } \\
\text { digging a line } \\
\text { along the } \\
\text { contour by } \\
\text { throwing } \\
\text { excavated soil } \\
\text { above the } \\
\text { ditch. }\end{array}$} & \multirow{3}{*}{$\begin{array}{ll}\text { - } & \text { It helps to conserve } \\
\text { soil moisture. } \\
\text { - } \\
\text { Reduce runoff } \\
\text { velocity and conserve } \\
\text { water. } \\
\text { Increase soil } \\
\text { infiltration rate and } \\
\text { increases ground } \\
\text { water potential. }\end{array}$} & \multirow[t]{3}{*}{$\begin{array}{l}\text { Physical } \\
\text { practice. }\end{array}$} & \multirow[t]{3}{*}{ SWC } & \multirow[t]{3}{*}{ Dry season } \\
\hline & & $\begin{array}{l}\text { Kajima } \\
\text { Umbullo } \\
\text { and } \\
\text { Tankaka } \\
\text { Umbullo. }\end{array}$ & Irkane & & & & & \\
\hline & & $\begin{array}{l}\text { Tuttiti and } \\
\text { worabi }\end{array}$ & & & & & & \\
\hline
\end{tabular}




\begin{tabular}{|c|c|c|c|c|c|c|c|}
\hline No. & $\begin{array}{l}\text { Name of } \\
\text { SWC } \\
\text { practice }\end{array}$ & Kebeles & $\begin{array}{l}\text { Local } \\
\text { name }\end{array}$ & $\begin{array}{l}\text { Implementing } \\
\text { system }\end{array}$ & Function & SWC category & $\begin{array}{l}\text { Implementing } \\
\text { season }\end{array}$ \\
\hline \multirow[t]{3}{*}{3.} & \multirow[t]{3}{*}{ Trench } & $\begin{array}{l}\text { Layigna } \\
\text { Arisho and } \\
\text { M/ } \\
\text { gortanicho. }\end{array}$ & Trencha & \multirow{3}{*}{$\begin{array}{l}\text { It was } \\
\text { constructed at } \\
\text { different } \\
\text { communal } \\
\text { lands and } \\
\text { closure areas } \\
\text { by excavating } \\
\text { a ditch with 2- } \\
5 \mathrm{~m} \text { length } \\
\text { along the } \\
\text { contour. }\end{array}$} & \multirow{3}{*}{$\begin{array}{ll}- & \text { Harvest and control } \\
\text { runoff water. } \\
\text { - } \\
\text { Increase ground water } \\
\text { potential. } \\
\text { - } \quad \text { Helps to rehabilitate } \\
\text { degraded lands. } \\
\text { - } \quad \text { Helps to conserve soil } \\
\text { moisture, etc. }\end{array}$} & \multirow[t]{3}{*}{$\begin{array}{l}\text { Physical } \\
\text { practice. }\end{array}$} & \multirow[t]{3}{*}{ Dry season } \\
\hline & & $\begin{array}{l}\text { Kajima } \\
\text { Umbullo } \\
\text { and } \\
\text { Tankaka } \\
\text { Umbullo. }\end{array}$ & Trenche & & & & \\
\hline & & $\begin{array}{l}\text { Tuttiti and } \\
\text { worabi }\end{array}$ & & & & & \\
\hline 3. & $\begin{array}{l}\text { Tied } \\
\text { ridge }\end{array}$ & $\begin{array}{l}\text { Layigna } \\
\text { Arisho and } \\
\text { M/ } \\
\text { gortanicho }\end{array}$ & tayrage & $\begin{array}{l}\text { Constructed to } \\
\text { harvest water } \\
\text { and improve } \\
\text { water } \\
\text { availability for } \\
\text { crops in farm } \\
\text { field. }\end{array}$ & $\begin{array}{lll}- & \text { Improves } & \text { water } \\
\text { availability for crops. } \\
\text { - } & \text { Conserve in situ- } \\
& \text { water. } & \\
\text { - } & \text { Increases } & \text { soil } \\
& \text { infiltration rate. } & \end{array}$ & $\begin{array}{l}\text { Physical } \\
\text { practice. }\end{array}$ & Wet season \\
\hline \multirow[t]{2}{*}{4.} & \multirow[t]{2}{*}{$\begin{array}{l}\text { Sand } \\
\text { filled } \\
\text { checkdam }\end{array}$} & $\begin{array}{l}\text { Layigna } \\
\text { Arisho and } \\
\text { M/ } \\
\text { gortanicho }\end{array}$ & $\begin{array}{l}\text { Ashawi } \\
\text { kuntala }\end{array}$ & \multirow{2}{*}{$\begin{array}{l}\text { It was done by } \\
\text { filling sacks } \\
\text { with sand/soil } \\
\text { and placing } \\
\text { different sand } \\
\text { filled sacks on } \\
\text { the gullies. }\end{array}$} & \multirow[t]{2}{*}{$\begin{array}{ll}- & \text { It helps to rehabilitate } \\
\text { large gullies erosion. } \\
\text { It used as a barrier for } \\
\text { run off on the gully. }\end{array}$} & \multirow[t]{2}{*}{$\begin{array}{l}\text { Physical/mechanical } \\
\text { SWC practices. }\end{array}$} & \multirow[t]{2}{*}{ Dry season. } \\
\hline & & $\begin{array}{l}\text { Kajima } \\
\text { Umbullo } \\
\text { and } \\
\text { Tankaka } \\
\text { Umbullo }\end{array}$ & $\begin{array}{l}\text { Ashawa } \\
\text { ogoro } \\
\text { wonisha }\end{array}$ & & & & \\
\hline \multirow[t]{2}{*}{5.} & \multirow[t]{2}{*}{ Gabion } & $\begin{array}{l}\text { Layigna } \\
\text { Arisho }\end{array}$ & gabun & \multirow{2}{*}{$\begin{array}{l}\text { It was } \\
\text { constructed by } \\
\text { using gabion } \\
\text { mesh and } \\
\text { stone on large } \\
\text { gullies. }\end{array}$} & \multirow{2}{*}{$\begin{array}{l}\text { - It helps to rehabilitate } \\
\text { large gullies. } \\
\text { It reduces run off } \\
\text { velocity and used as a } \\
\text { barrier for runoff on } \\
\text { the gully. }\end{array}$} & \multirow[t]{2}{*}{$\begin{array}{l}\text { Physical/mechanical } \\
\text { SWC practices. }\end{array}$} & \multirow[t]{2}{*}{ Dry season. } \\
\hline & & $\begin{array}{l}\text { Kajima } \\
\text { Umbullo } \\
\text { and } \\
\text { Tankaka } \\
\text { Umbullo } \\
\end{array}$ & gabonete & & & & \\
\hline 6. & $\begin{array}{l}\text { Farm } \\
\text { pond }\end{array}$ & $\begin{array}{l}\text { Layigna } \\
\text { Arisho and } \\
\text { M/ } \\
\text { gortanicho }\end{array}$ & Haro/Kure & $\begin{array}{l}\text { Constructed } \\
\text { near to farm } \\
\text { field to irrigate } \\
\text { crops during } \\
\text { scarce rainfall. }\end{array}$ & $\begin{array}{llr}- & \text { It helps to irrigate } \\
\text { crops at dry season. } \\
\text { - } & \text { Reduces } & \text { water } \\
\text { scarcity. } & \end{array}$ & $\begin{array}{l}\text { Physical/mechanical } \\
\text { SWC practices. }\end{array}$ & Dry season. \\
\hline 7. & $\begin{array}{l}\text { Improved } \\
\text { pit }\end{array}$ & $\begin{array}{l}\text { Tutitti and } \\
\text { worabi }\end{array}$ & Gudguad & $\begin{array}{l}\text { Excavating a } \\
\text { pit with the } \\
\text { specified size } \\
(50 \times 50 \mathrm{~cm}) \\
\text { inside coffee } \\
\text { farm. }\end{array}$ & $\begin{array}{l}\text { - } \quad \text { It helps to conserve in- } \\
\text { situ water. } \\
\text { It improves crop water } \\
\text { availability especially } \\
\text { for coffee. }\end{array}$ & $\begin{array}{l}\text { Physical } \\
\text { practice. }\end{array}$ & $\begin{array}{l}\text { Wet and dry } \\
\text { seasons. }\end{array}$ \\
\hline 8. & $\begin{array}{l}\text { Grass } \\
\text { strip }\end{array}$ & $\begin{array}{l}\text { Kajima } \\
\text { Umbullo }\end{array}$ & Hayiso & $\begin{array}{l}\text { Planting of } \\
\text { elephant and } \\
\text { desho grass } \\
\text { horizontally } \\
\text { along the } \\
\text { contour on } \\
\text { farm lands. }\end{array}$ & $\begin{array}{l}\text { - It helps to control soil } \\
\text { erosion by reducing } \\
\text { rain drops effect and } \\
\text { reducing runoff } \\
\text { velocity. } \\
\text { In addition to erosion } \\
\text { controlling effect it is } \\
\text { forage for animals. }\end{array}$ & $\begin{array}{l}\text { Biological } \\
\text { practice. }\end{array}$ & Wet season \\
\hline 9. & $\begin{array}{l}\text { Micro } \\
\text { bezin and } \\
\text { Eyebrow } \\
\text { bezin }\end{array}$ & $\begin{array}{l}\text { Kajima } \\
\text { Umbullo } \\
\text { and } \\
\text { Tankaka } \\
\text { Umbullo }\end{array}$ & - & $\begin{array}{l}\text { It was } \\
\text { constructed in } \\
\text { half moon } \\
\text { shape along } \\
\text { the contour. }\end{array}$ & $\begin{array}{ll}\text { - } & \text { It helps to } \\
\text { conserve/harvest } \\
\text { water. } \\
\text { It improves water } \\
\text { availability for tree } \\
\text { planted on the } \\
\text { structure. } \\
\text { It is important to } \\
\text { reclaim degraded area. }\end{array}$ & $\begin{array}{l}\text { Physical/mechanical } \\
\text { SWC practices. }\end{array}$ & Dry season. \\
\hline
\end{tabular}

Source: survey data, 2019.

10. Limitations in practicing soil and water conservation activities of study area.

During transect walk with development agents we observed various site specific challenges with soil and water conservation activities. At Mirab Gortanicho kebele, Layigna Arisho, Tankaka Umbullo and Kajima Umbullo Kebeles we observed many destructed structures which were constructed by free community participation each year. The respondents indicate that the farmers were not aware about the effect of physical soil and water conservation practices. The developments agents also indicate that the destruction of the structures at Mirab Goritanicho was for the search of cropping land. In addition to that during transect walk we have observed different physical structures done by public campaign were not designed and excavated appropriately. The structures maintenance was not undertaken at regular time. Some of the bunds were not stabilized by biological stabilizers. 
However, most farmers did not practice technically sound soil and water

Conservation activities due to social, economical, environmental and political factors. Some of the major factors reported were: Land size: it is closely associated with soil fertility and soil erosion perception of farmers thus farmers with large farm holding perceive soil erosion better than those with smaller one. They practice traditional fallowing and also allot enough plot of grazing land for their cattle that help to mitigate soil erosion and fertility depletion.

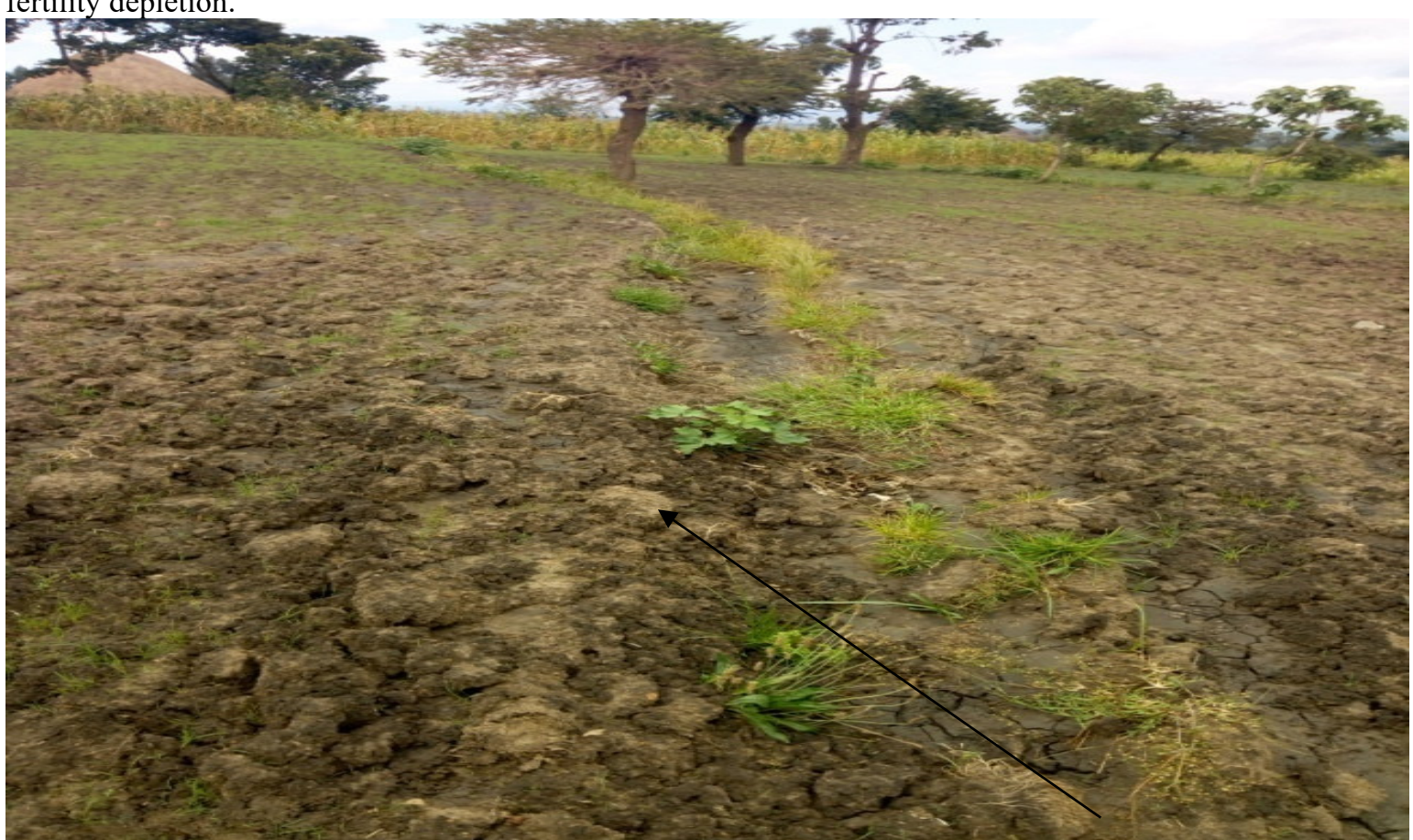

Figure: Soil and water conservation bunds destructed to increase crop land size at Mirab Gortanicho kebele, Wera Zuria woreda.

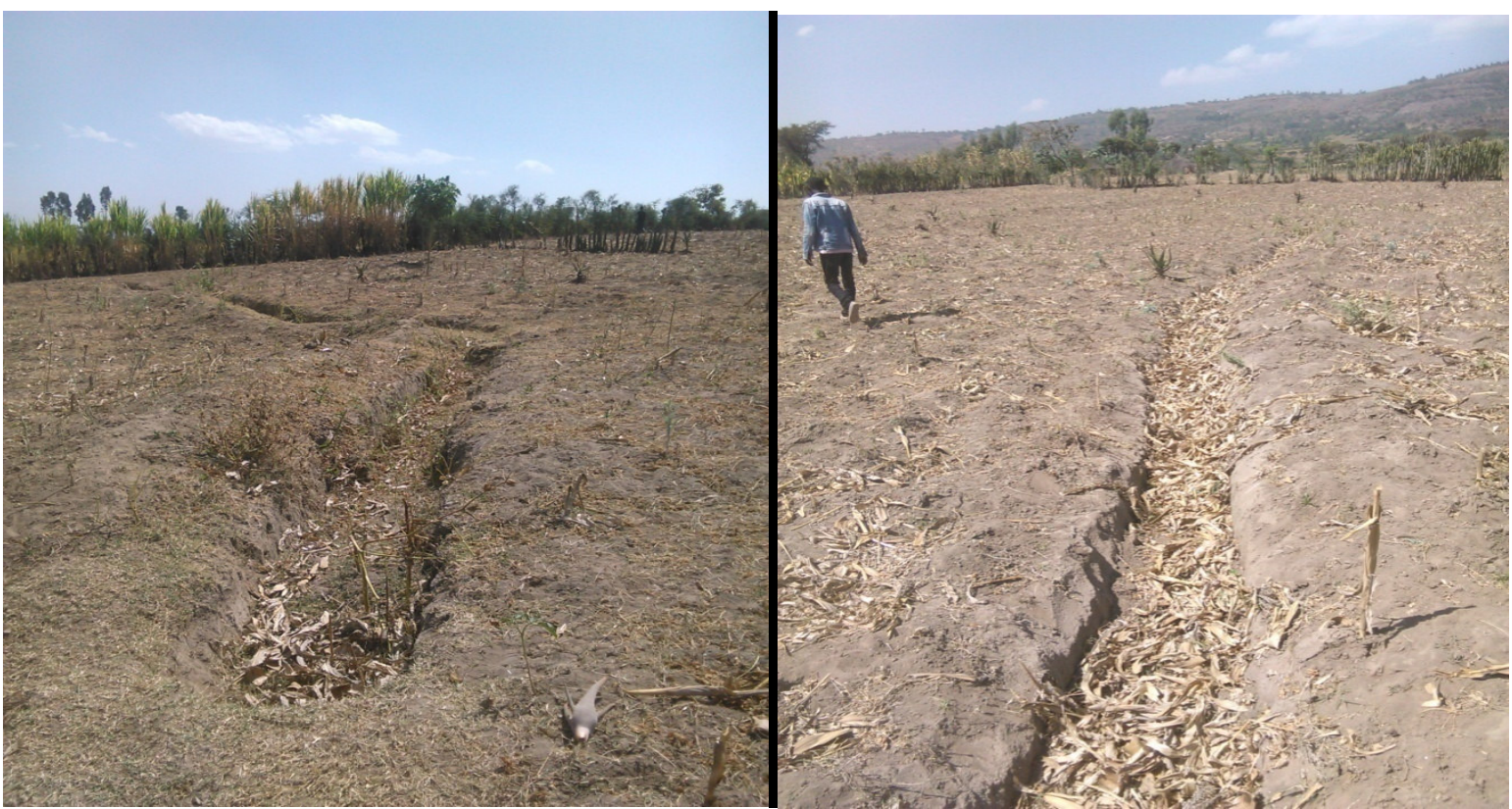

Figure: Physical structures which were not well designed on farm lands at Tankaka Umbullo kebele.

\section{Conclusion and Recommendation}

From this study we conclude and recommend that:

1. Some physical structures implemented lacks quality and were not designed according to the SWC principle.

2. Indigenous SWC practices are basic for introduced practices. There were different indigenous practices 
which were practiced at specific district but not at other district. So, all stake holders' bodies should promote to another areas.

3. There is a gap on implementation, evaluation, regular maintenance and management works of physical structures. So, the task needs serious attention.

4. Different research and Pre-scaling up works on soil and water conservation needs be done to further aware, familiarize and reduce deliberate destruction of bunds by land owners.

\section{References}

BoFED, 2004. Regional Atlas. Southern Nation, Nationalities and PeoplesRegional State, Bureau of Finance and Economic Development, Bureau ofStatistics and population. Awassa, Ethiopia

CSA Central Statistical Agency (2007) Population and housing census report. Addis Ababa, Ethiopia.

Tsegaye G. and Gebremichael A. 2014. Review on Overall Status of Soil and Water Conservation System and Its Constraints in Different Agro Ecology of Southern Ethiopia Journal of Natural Sciences Research. www.iiste.org. ISSN 2224-3186 (Paper) ISSN 2225-0921 (Online) Vol.4, No.7,

Mitiku Haile, Karl Herweg and Brigitta stillhard, 2006. Sustainable land management - a new approach to soil and water conservation in Ethiopia, Mekele University, and Swiss Centre for Development and Environment, National Centre of Competence in Research (NCCR) norh-south university of bern, Switzerland.

Akilu Amsalu, (2001). Natural Resource Management in Ethiopia. Making Good use of Indigenous knowledge. Ethiopian Development Forum Bulletin of institute of development Research. AAU.Vol2, (1) p2-16.

Abegaz G (1995). Soil erosion assessment: Approaches, magnitude of the problem and issues on policy and strategy development. Paper presented at the Workshop on Regional NRM Potential sand Constraints, Bahir Dar, Ethiopia.

Hurni H (1983). Soil formation rate in Ethiopia. Working paper 2. FAO (Food and Agriculture Organization of the United Nations) /MOA (Ministry of Agriculture) joint project, Ethiopian Highlands Reclamation Study, Addis Ababa, Ethiopia.

Hurni H (1990). Degradation and Conservation of the Soil Resources in the Ethiopian Highlands. In African Mountains and Highlands: problems and Prospectives. pp. 51-64. 